\title{
A new genus of mygalomorph spider from the Great Victoria Desert and neighbouring arid country in south-eastern Western Australia (Araneae: Nemesiidae)
}

\author{
Barbara York Main ${ }^{1,3}$ and Volker W. Framenau ${ }^{1,2}$ \\ ${ }^{1}$ School of Animal Biology, University of Western Australia, Crawley, Western Australia 6009, Australia \\ E-mail: bymain@cyllene.uwa.edu.au \\ ${ }^{2}$ Department of Terrestrial Zoology, Western Australian Museum, Locked Bag 49, Welshpool DC, \\ Western Australia, 6986. Australia. E-mail: volker.framenau@museum.wa.gov.au \\ ${ }^{3}$ Corresponding author
}

\begin{abstract}
Swolnpes, a new genus in the mygalomorph spider family Nemesiidae, is described from the Great Victoria Desert and the Morgan Ranges in south-eastern Western Australia. Swolnpes includes two new species, S. darwini (type species) and S. morganensis, both of which are currently known from males only. Based on the configuration of the male pedipalp the genus is tentatively placed into the tribe Anamini Simon 1889, although some somatic characters, such as the lack of a tibial spur and the lack or low number of maxillary cuspules which are restricted to a narrow band, are reminiscent of the genus Teyl Main 1975 (tribe Teylini Main 1985).
\end{abstract}

\section{INTRODUCTION}

The mygalomorph spider family Nemesiidae Simon 1892 currently includes twelve genera in Australia of which eight are reported from Western Australia: Aname L. Koch, 1873, Chenistonia Hogg, 1901, Kwonkan Main, 1983, Merredinia Main, 1983, Pseudoteyl Main, 1985, Stanwellia Rainbow \& Pulleine, 1918, Teyl Main, 1975, and Yilgarnia Main, 1986. The taxonomy of the family in Australia was reviewed over 20 years ago (Raven 1981, 1985) and for an identification of some of the Western Australian genera established since then, original descriptions have to be consulted: Main (1985) for Pseudoteyl and Main (1986) for Yilgarnia. The taxonomy of some genera, for example Chenistonia, remains disputed (BYM unpublished data, but see Raven (2000)), and the generic limits between Kwonkan and Yilgarnia are unclear as spiders have been found that show the synapomorphies of both genera (e.g. Main et al. 2000). Much needs to be learnt about the Australian Nemesiidae, which is not surprise taking into account the unresolved limitations of the family (e.g., Goloboff 1995; Hedin and Bond 2006).

In recent years, Environmental Impact Assessment (EIA) surveys for proposed mining projects have resulted in unprecedented collections of terrestrial invertebrates in Western Australia. Of particular interest are those taxonomic groups that are potentially threatened by habitat destruction due to their restricted distribution.
These include, amongst others, snails, millipedes and mygalomorph (trapdoor) spiders (Harvey 2002; Environmental Protection Authority 2009). A number of male mygalomorph specimens that were collected during a survey for short-range endemic fauna in an area of the Great Victoria Desert in Western Australia (designated as "Tropicana" mining lease) by Ecologia Environment, Perth, could not be attributed to one of the named genera. Several similar specimens in the Western Australian Museum collections were already known from the Morgan Ranges collected during a joint expedition by the Western Australian and South Australian Museums and the Department of Environment and Conservation, Western Australia (DEC) in 2006. Although readily assignable to the Nemesiidae and with some features shared by certain Aname species and others by the genus Teyl, the specimens exhibit distinctive morphological characters not known in any of the named genera. Although no female specimens of the new species are currently known, the unusual morphological characters of males in combination with the putatively high conservation value (of the species) justify establishing a new genus for the species described herein. The new genus shares some morphological features with an undescribed species known from the Carnarvon Basin survey and cited as attributable to a new genus (Main et al. 2000). It is not surprising, that previously unknown genera of mygalomorph spiders are still being found in Western Australia as many remote and 
varied habitats have not been intensively surveyed.

This study describes two species in a new genus of nemesiid spiders to commemorate the $200^{\text {th }}$ anniversary of Charles Darwin's birth in 1809 and the $150^{\text {th }}$ anniversary of the publication of his The Origin of Species by Means of Natural Selection (Darwin 1859).

\section{METHODS}

Specimens of Swolnpes darwini sp. nov. were collected from wet pitfall traps containing a mixture of formaldehyde and alcohol and stored in $75 \%$ ethyl alcohol. This collecting medium rendered the specimens very stiff, making examination for taxonomic work difficult. Specimens of Swolnpes morganensis sp. nov. were collected in dry pitfall traps and immediately transferred into $75 \%$ ethyl alcohol. Specimens were examined with Zeiss Citoval and Leica MZ6 dissecting microscopes and measurements made using an eyepiece micrometer. Measurements are in millimetres. Drawings were made on tracing paper overlaid on millimetre/ centimetre graph paper while viewing a specimen with a squared graticule in the microscope eyepiece. Photographs were taken in different focal planes (ca. 20-30 images) with a Leica DFC500 digital camera that was attached to a Leica MZ16A stereo microscope and combined with the Leica Application Suite version 2.5.OR1.

The "leg formula" is here given as the leg length divided by the carapace length. The "tibial index" is defined as: (dorsal proximal width of patella/ length of tibia + patella) x 100. It is a measurement for the 'stoutness' of the legs (Petrunkevitch 1942). Total length is measured dorsally including the chelicerae, but excluding the spinnerets.

Specimens are lodged in the Western Australian Museum, Perth (WAM) and the Queensland Museum, Brisbane (QM) (some remain temporarily in the Barbara York Main collection, housed in the School of Animal Biology, University of Western Australia (BYM)).

\section{SYSTEMATICS}

\section{Family Nemesiidae Simon, 1892}

\section{Tribe Anamini Simon, 1889}

Swolnpes gen. nov.

\section{Type species}

Swolnpes darwini sp. nov.

\section{Diagnosis}

Swolnpes males differ from all other genera within the Nemesiidae by the synapomorphy of an inflated tarsus of the first leg that carries a ventral pad of short, stubby, spine-like bristles forming a brush instead of a scopula of fimbriated setae (Figures 1E, 3C, D, 4D, E). Females are currently unknown.

\section{Description}

Males

Small nemesiid spiders (total length 6.1-8.6, carapace length 2.4-3.3, carapace width 2.3-2.8). Uniformly yellow-brownish with somewhat darker cephalic area; abdomen with (S. darwini) or without (S. morganensis) darker dorsal pattern. Eye group 2.5-2.9 times wider than long. Sternal sigillae broad, transverse but barely perceptible (Figure 1B). Labium wider than long, slightly indented anteriorly. Maxillae without or only few (less than ca. 20) pin-like cuspules, not extending to heel. Abdomen longer than wide. Four spinnerets, terminal segment of posterior lateral spinnerets digitiform.

Tarsi and metatarsi of leg I inflated, tarsus ventrally with a uniform pad or brush of dense, fine but stubby spine-like bristles in place of a typical scopula. Paired tarsal claws of leg I (II-IV) with two rows of 10-15 (5-10) teeth each, third tarsal claw reduced and very small. Tibia I without spur or megaspine. Metatarsi I with 1-3 prolateral and 4-10 ventral spines ( 3 in a cluster apically); tibia I with 2-3 prolateral, $0-2$ retrolateral and 6-8 ventral spines (mainly in apical half); patella with 0 (S. darwini) or 2 (S. morganensis) prolateral spines; femora with 4-8 dorsal and 0-2 prolateral spines.

Tarsi, metatarsi and tibiae with 5-15 dorsal trichobothria (sometimes in loose pairs); tarsal trichobothria apically longer, metatarsal and tarsal trichobothria of equal length along segment. Metatarsus apico-dorsally with pronounced condyle (e.g. Figure 3D).

Pedipalp tarsus short and terminally blunt (as in Aname); palpal bulb elongate, embolus tapering; pedipalp tibia with slight apico-ventral depression (accommodates bulb and embolus) (Figures 1C, 3F, 5B).

\section{Females}

Unknown.

\section{Etymology}

The generic name combines swoln with the Latin word pes (foot) in reference to the swollen tarsi and metatarsi of the first legs. The gender is masculine.

\section{Remarks}

Spiders resemble certain Aname, Kwonkan and Yilgarnia in the configuration of the pedipalp, such as a short tarsus, an elongated bulb and basally 
broad and tapering embolus and are therefore considered members of the tribe Anamini Simon, 1889. However, they differ from above genera in the absence of a tibial spur on the first leg and having few maxillary cuspules, which are restricted to a narrow band, similar to Teyl in the Teylini Main, 1985 (but see Hedin and Bond (2006) for an assessment of the monophyly of both tribes).

\section{Distribution}

Swolnpes is found in south-eastern Western Australia (Figure 6).

\section{Swolnpes darwini sp. nov.}

Figures 1-3, 6

\section{Holotype}

Australia: Western Australia: $\widehat{\delta}$, Great Victoria Desert, "Tropicana" mining lease, AngloGold Ashanti, $450 \mathrm{~km}$ NE of Kalgoorlie, Ecologia Environment Site 46, 29 ${ }^{\circ} 15^{\prime} 03.024^{\prime \prime} \mathrm{S} 124^{\circ} 35^{\prime} 34.548^{\prime \prime} \mathrm{E}$, wet pitfall trap, 1 August-1 September 2008, AngloGold Ashanti staff, 716-263b, BYM 2008/354 (WAM T97486).

\section{Paratypes}

Australia: Western Australia: 2 , data as for holotype, except BYM2008/355-6 (WAM T97487); $20^{\wedge}$, same data, except Site 44, 29 $15^{\prime} 26.244^{\prime \prime} \mathrm{S}$ $124^{\circ} 35^{\prime} 51.108^{\prime \prime} \mathrm{E}$, June-July 2008, 716-164, BYM 2008/51-2 (WAM T97003-4).

Other material examined

\section{Material examined}
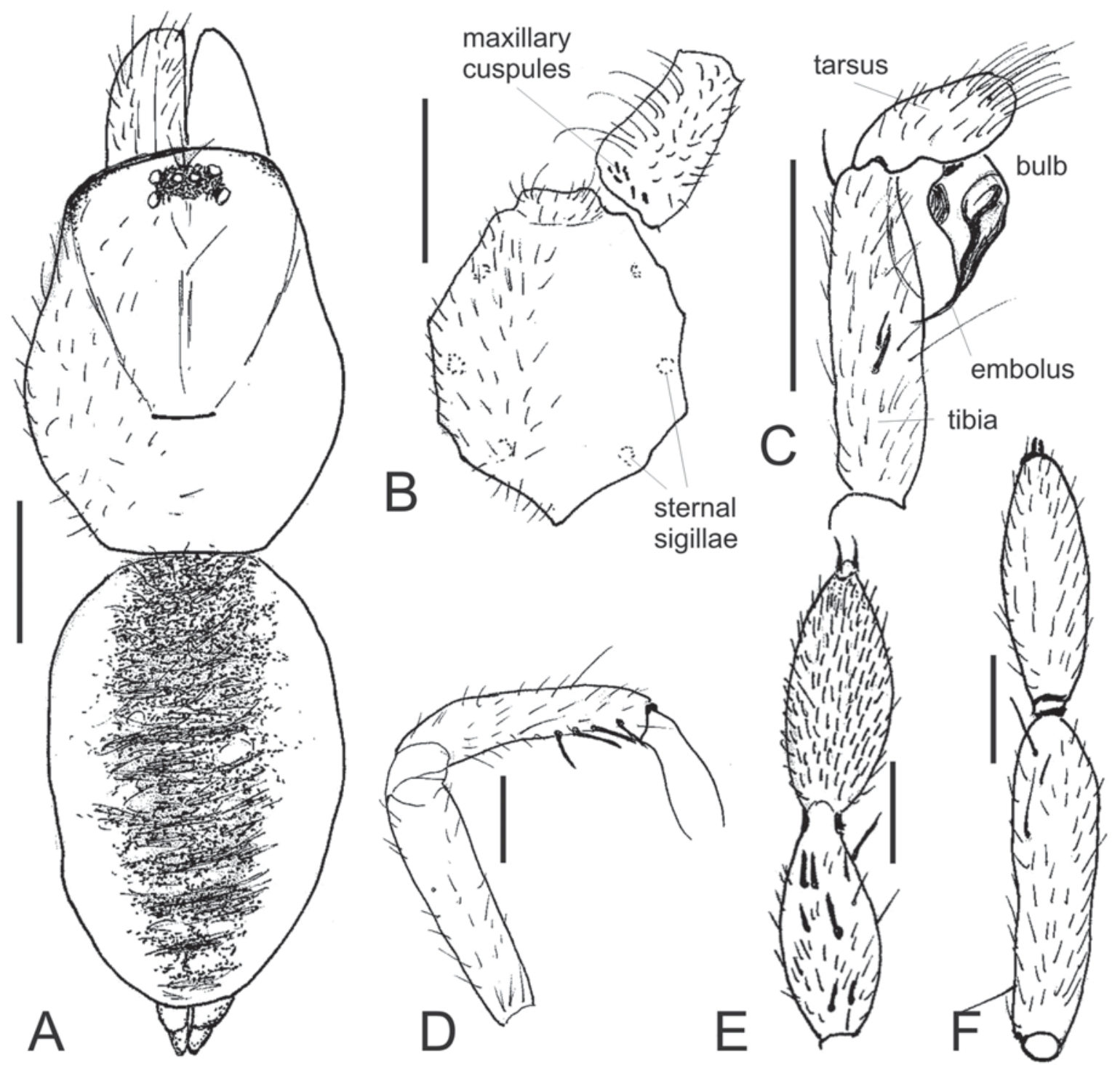

Figure 1 Swolnpes darwini sp. nov., male holotype (WAM T97486, from the Great Victoria Desert, Western Australia): (A) habitus, dorsal view; (B) sternum and left maxilla, ventral view; (C) right male pedipalp, retrolateral view; (D) right male leg I, retrolateral view; (E) right male leg I tarsus and metatarsus, ventral view; (F) right male leg II tarsus and metatarsus, ventral view. Scale bars: $1 \mathrm{~mm}$. 

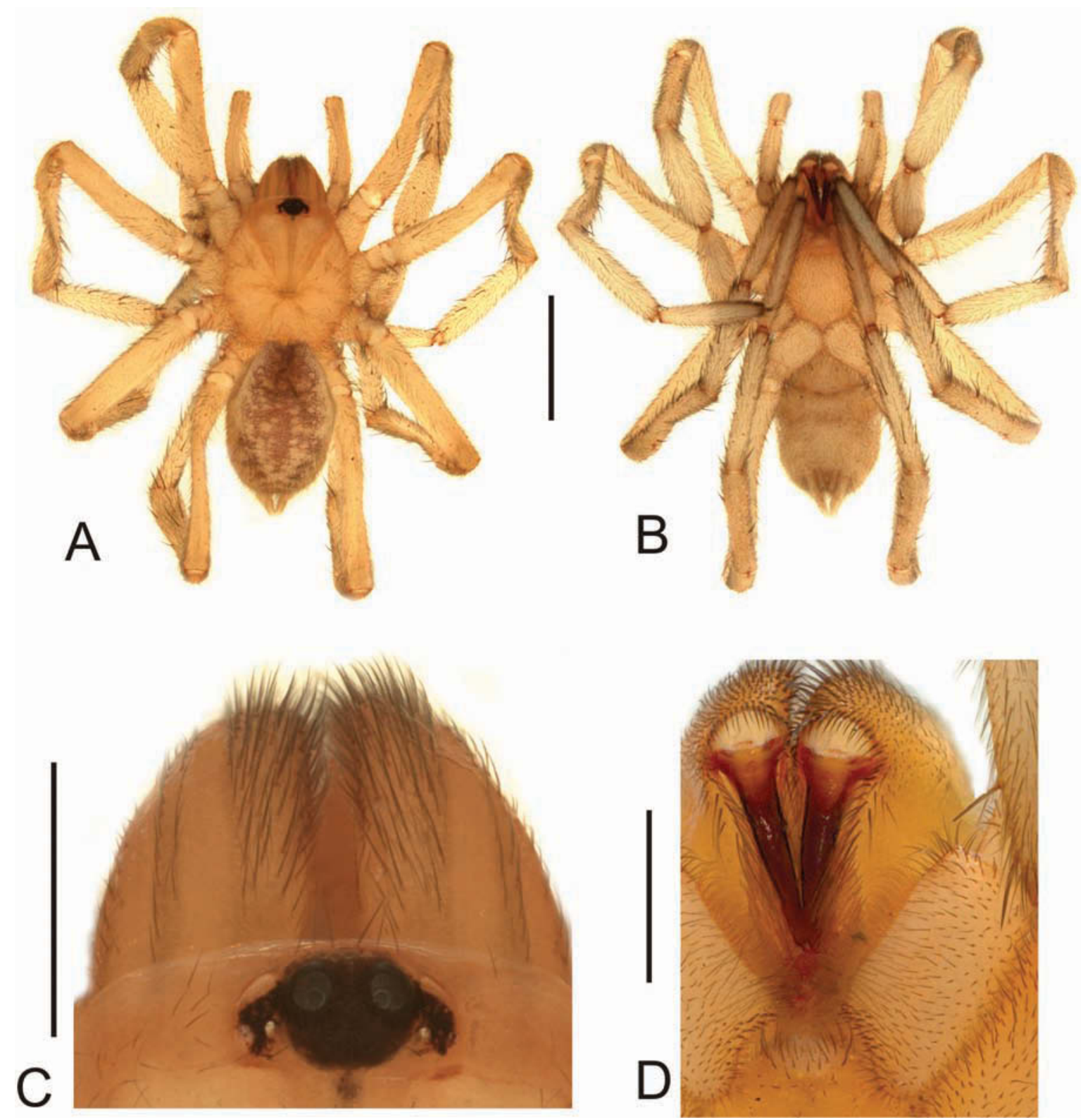

Figure 2 Swolnpes darwini sp. nov.: A-C, male paratype (WAM T97003, from the Great Victoria Desert, Western Australia): habitus, dorsal (A) and ventral (B) view; eye region, dorsal view (C). D, male paratype (WAM T97004, from the Great Victoria Desert, Western Australia), labium, maxillae and chelicerae, ventral view. Scale bars: A, B, $3 \mathrm{~mm}$; C, D, $1 \mathrm{~mm}$.

Australia: Western Australia: 1 กे, Great Victoria Desert, “Tropicana” mining lease, AngloGold Ashanti, $450 \mathrm{~km}$ NE Kalgoorlie, Ecologia Environment Site 33, $29^{\circ} 08^{\prime} 02^{\prime \prime} \mathrm{S} 124^{\circ} 37^{\prime} 28^{\prime \prime} \mathrm{E}$, wet pitfall trap, 30 June-29 July 2008, AngloGold Ashanti staff, 716-192, BYM 2008/205 (WAM

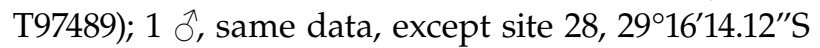
$124^{\circ} 35^{\prime} 40.63^{\prime \prime}$, June-July 2008, 716-182, BYM 2008/53 (WAM T97490); 2 Oे, same data, except site 45, 29 $15^{\prime} 19^{\prime \prime} \mathrm{S} 124^{\circ} 35^{\prime} 43^{\prime \prime} \mathrm{E}, 1$ August-1 September 2008, EE716-309b, BYM 2008/369-70 (WAM T97491); 1 ${ }^{\lambda}$, same data, except site $28,29^{\circ} 16^{\prime} 14^{\prime \prime} \mathrm{S}$ 124'35'40"E, EE716-297b, BYM 2008/364 (WAM


$124^{\circ} 43^{\prime} 15.49^{\prime \prime}$, April-May 2008, 716-071, BYM
2008/46 (WAM T97493); 2 ऽે, same data, except site $32,2^{\circ} 16^{\prime} 55^{\prime \prime} \mathrm{S} 124^{\circ} 35^{\prime} 55^{\prime \prime} \mathrm{E}, 1$ August-1 September 2008, EE716-312b, BYM 2008/371-2 (WAM T97494); 1 O), same data, except site $46,2^{\circ} 15^{\prime} 03^{\prime \prime} \mathrm{S} 124^{\circ} 35^{\prime} 34^{\prime \prime} \mathrm{E}$, 30 June-29 July 2008, 716-209b, BYM 2008/210 (WAM T97495); $1 \hat{\delta}$, same data, except site 37 , $29^{\circ} 09^{\prime} 48.46^{\prime \prime S} 124^{\circ} 38^{\prime} 59.75^{\prime \prime} \mathrm{E}$, June-July 2008, 716061, BYM 2008/39-40 (WAM T97496); 3 ${ }^{\lambda}$, same data, except site $44,2^{\circ} 15^{\prime} 26^{\prime \prime} \mathrm{S} 124^{\circ} 35^{\prime} 51^{\prime \prime} \mathrm{E}, 1$ August-1 September 2008, EE716-301b, BYM 2008/365-7 (WAM T97497); 7 ô, same data, except site 29, $29^{\circ} 16^{\prime} 27^{\prime \prime} \mathrm{S} 124^{\circ} 35^{\prime} 46^{\prime \prime} \mathrm{E}, 1$ August-1 September 2008, EE716-331b, BYM 2008/344-50 (WAM T97498); 10 d, same data, except site 33, $29^{\circ} 16^{\prime} 14^{\prime \prime} \mathrm{S} 124^{\circ} 35^{\prime} 40^{\prime \prime} \mathrm{E}, 1$ August-1 September 2008, 

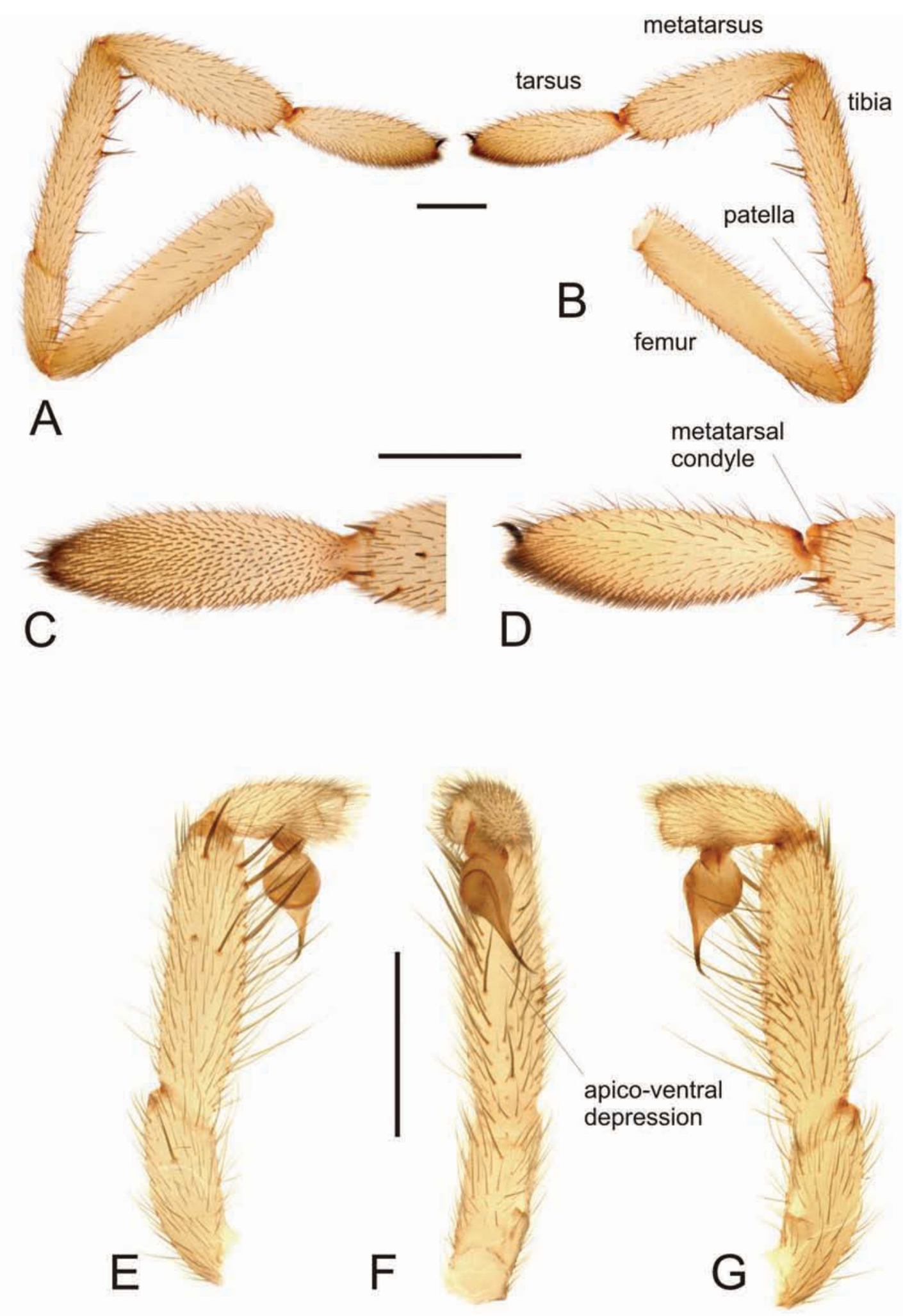

Figure 3 Swolnpes darwini sp. nov.: A-D, male paratype (WAM T97004), from Great Victoria Desert, Western Australia): right leg I, retrolateral (A) and prolateral (B) view; right leg I: tarsus, ventral (C) and prolateral (D) view. E-G, male paratype (WAM T97003), from the Great Victoria Desert, Western Australia), left pedipalp, prolateral $(\mathrm{E})$, ventral $(\mathrm{F})$ and retrolateral $(\mathrm{G})$ view. Scale bars: $1 \mathrm{~mm}$. 

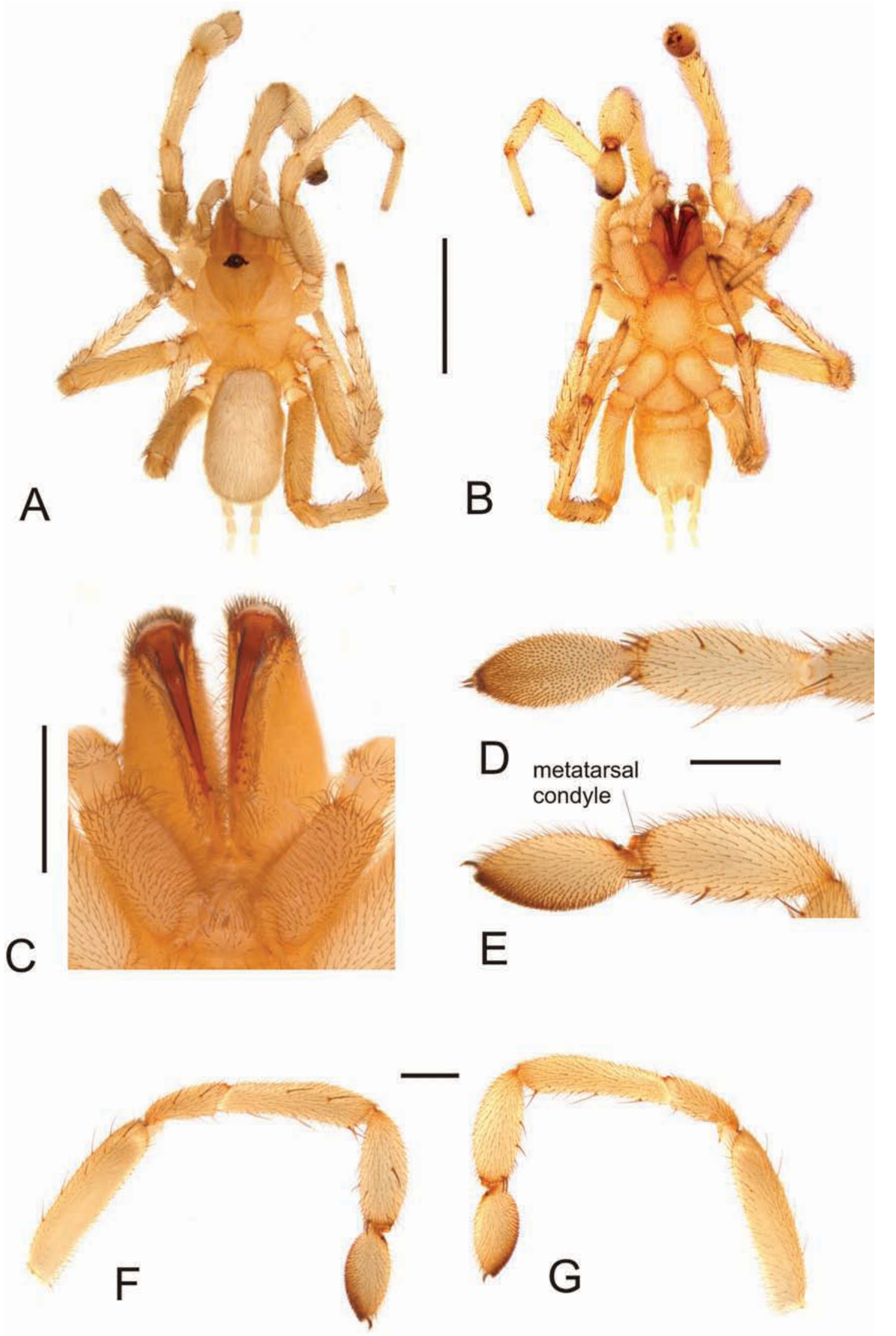

Figure 4 Swolnpes morganensis sp. nov.: A-B, male holotype (WAM T97333), from Morgan Ranges, Western Australia): habitus, dorsal (A) and ventral (B) view. C-G, male paratype (WAM T97348), from Morgan Ranges, Western Australia): (C) labium, maxillae and chelicerae, ventral view; left leg I, tarsus and metatarsus: ventral (D) and retrolateral (E) view; left leg I: prolateral $(F)$ and retrolateral $(G)$ view. Scale bars: A, B, 3 mm; C-G, 1 mm. 
EE716-299b, BYM 2008/334-43 (WAM T97499); 2


EE716- 316b, BYM 2008/352, 353 (WAM T97500); 2 $\mathrm{O}^{\prime}$, same data, except site $44,2^{\circ} 15^{\prime} 26^{\prime \prime} \mathrm{S} 124^{\circ} 35^{\prime} 51^{\prime \prime} \mathrm{E}$, 30 June-29 July 2008, 716-212b, BYM 2008/213 \& 213A (WAM T97501); $1 \hat{\sigma}$, same data, except site


716-216b, BYM 2008/216 (WAM T97502); 1 ते, same

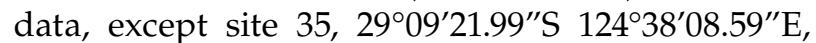
July 2008, EE716-120 (WAM T97503) ; $1 \hat{\jmath}$, same data, except site $28,29^{\circ} 16^{\prime} 14^{\prime \prime} \mathrm{S} 124^{\circ} 35^{\prime} 40^{\prime \prime} \mathrm{E}$, July 2008, EE716-181 (WAM T97504); $3 \hat{\jmath}$, same data, except site $46,2^{\circ} 15^{\prime} 03.024^{\prime \prime} \mathrm{S} 124^{\circ} 35^{\prime} 34.548^{\prime \prime} \mathrm{E}$, June-July 2008, EE716-153, BYM2008/47-49 (QM S88080).

\section{Diagnosis}

Swolnpes darwini males differ from those of $S$. morganensis by their relatively shorter and less inflated tarsi and metatarsi of leg I (Figures 3A-D vs Figures $4 \mathrm{D}-\mathrm{G})$, dark pattern on the abdomen (uniformly yellow-brown in $S$. morganensis) (Figures 1A, 2A vs Figure 4A) and a basally straight embolus that is terminally pointed (embolus basally curved and less pointed in S. morganensis) (Figures 3E-G vs Figures $5 \mathrm{~A}-\mathrm{C}$ ). Females of neither species are currently known.

\section{Description}

\section{Male (based on holotype)}

Colour: generally tan/yellow, ocular area black, abdomen with dorsal dark brown pattern (Figure 1A; see also paratype Figure 2A).

Carapace: length 3.0, width 2.7 (total length 7.6). Eye group 0.7 wide, 0.3 long. Fovea slightly procurved.

\section{Sternum plus labium: length 2.0.}

Maxillae: with few (less than 20) pin-like cuspules, not extending to heel (Figure 1B; see also paratype Figure 2D).

Legs (Figures 1D-F; see also paratype Figure 3AD): Metatarsus I with three fine dorsal apical spines and five ventral spines and several heavy bristles. Tibia I retrolaterally with four delicate spines on retro-ventral edge. Numerous spines on all faces of tibia and metatarsi of legs III and IV, tarsi elongate with dense, fine spine-like bristles (longer but not compact as in pad on tarsus I).

Leg measurements: length of legs I=II=III $<\mathrm{IV}$; Leg I: femur 3.3, patella 1.5, tibia 2.6, metatarsus 2.5, tarsus 2.0, Total $=11.9$. Dorsal proximal width of patella I $=0.4$, tibial index $=9.2$, leg I formula $=3.1$. Leg IV: femur 3.5, patella 1.1, tibia 3.7, metatarsus 3.9, tarsus 2.4. Total $=14.6$. Dorsal proximal width of patella IV $=0.4$, tibial index = 8.7; leg IV formula $=4.0$.

Pedipalp: length of femur 1.9, patella 1.0, tibia 1.4, tarsus (dorsal) 0.7; embolus basally straight with acute tip (as in paratype, Figures 3E-G).

Abdomen: length 3.5, width 2.3.

Variation: total length 6.1-7.5, carapace length 2.4-3.1, carapace width 2.3-3.0 $(n=10)$. Maxillary cuspules absent in some specimens.

Female

Currently unknown.

\section{Etymology}

The specific epithet is a patronym in honour of Charles Darwin (1809-1882), whose insights and theories regarding evolution and biodiversity have served as a lasting inspiration to biologists.

\section{Distribution and habitat}

Swolnpes darwini is currently only known from the "Tropicana" mining lease in the Great Victoria Desert, Western Australia (Figure 6). The species must currently be considered a short-range endemic after Harvey (2002).

All sites comprised sandy or sandy loam or sandy clay soil with vegetation ranging from mallee, mulga or other acacias, and with some Callitris; all except sites 32, 33 and 37 had Triodia present.

\section{Swolnpes morganensis sp. nov.}

Figures 4-6

\section{Material examined}

Holotype

Australia: Western Australia: $\widehat{\jmath}$, Morgan Range, $25^{\circ} 53^{\prime} 30.4^{\prime \prime} \mathrm{S} 128^{\circ} 25^{\prime} 37.9^{\prime \prime} \mathrm{E}, 28$ September-3 October 2006, dry pitfall trap, site 25, K.E.C. Brennan, J.M. Waldock (WAM T79333).

Paratypes

Australia: Western Australia: $2 \hat{\sigma}$, as for holotype (WAM T97348-9).

\section{Diagnosis}

Swolnpes morganensis males differ from those of $S$. darwini by the more inflated tarsi and metatarsi of the first leg, the uniform yellow-brown colouration of the abdomen (dark pattern in S. darwini) and the basally curved embolus (straight in S. darwini) that also has a less pointed tip. The female of this species is currently unknown.

\section{Description}

\section{Male (based on holotype)}

Colour: generally yellowish-brown, cephalic area somewhat darker, ocular area black, abdomen uniformly yellowish-brown (Figures 4A,B).

Carapace: length 2.9, width 2.5 (total length 

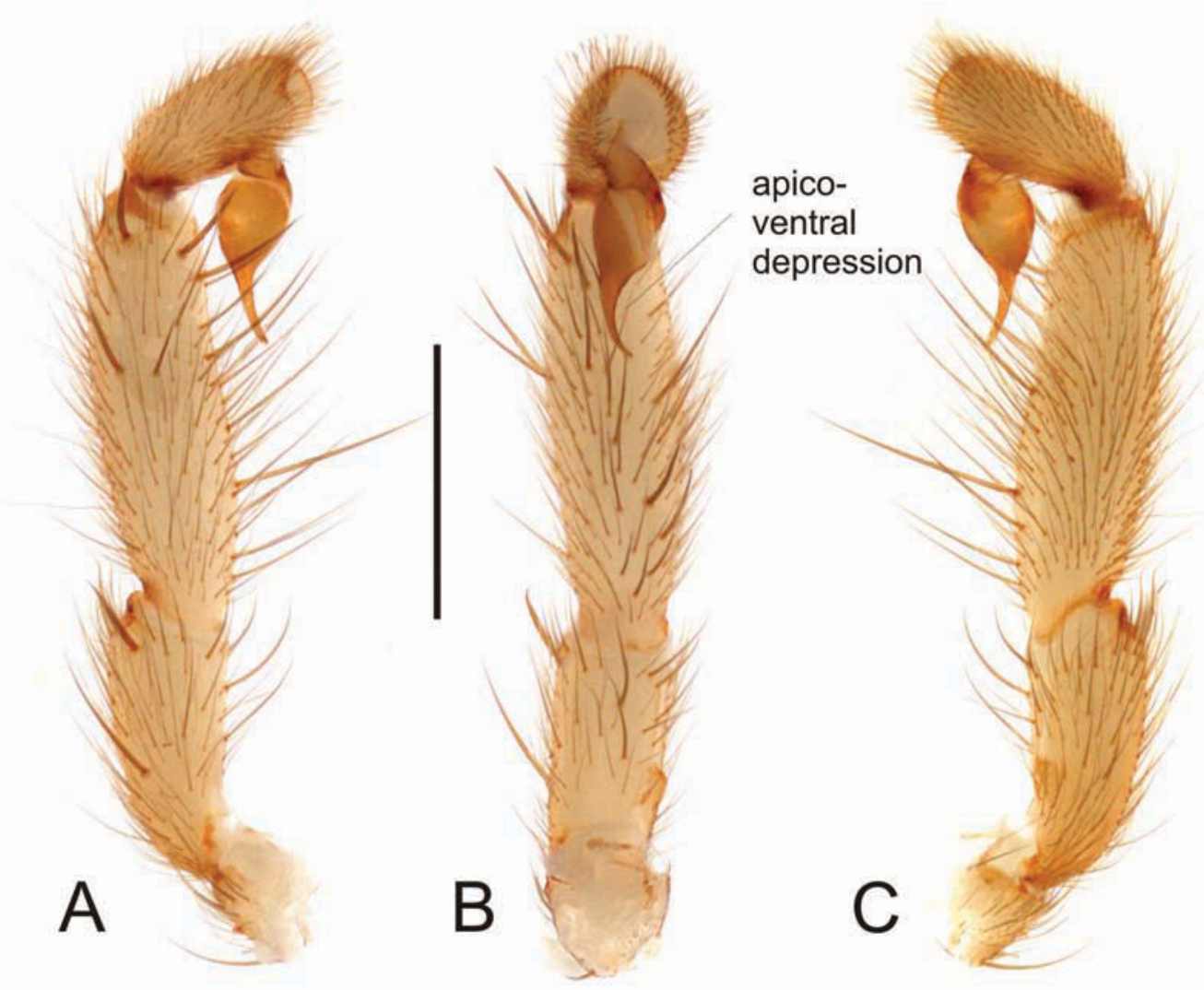

Figure 5 Swolnpes morganensis gen. nov. and sp. nov.: A-C - male paratype (WAM T97348), from Morgan Ranges, Western Australia): left pedipalp, prolateral (A), ventral (B) and retrolateral (C) view.

7.2). Eye group 0.7 wide, 0.25 long. Fovea slightly procurved.

\section{Sternum plus labium: length 2.0.}

Maxillae: without cuspules (as in paratype, Figure 4 C).

Legs (as in paratype, Figures 4D-G): Metatarsus I with 2 (left leg 1) prolateral spines and 3 ventral spines in apical half. Tibia I with 2 prolateral and 2 retrolateral (left leg 1) spines and ventrally with 6 (left leg 7) spines. Numerous spines on all faces of tibia and metatarsi of legs III and IV, tarsi elongate with dense, fine spine-like bristles (longer but not compact as in pad on tarsus I).

Leg measurements: length of legs IV $>$ I $>$ II $>$ III; Leg I: femur 3.0, patella 1.3, tibia 2.3, metatarsus 1.8, Tarsus 1.5, Total $=9.9$. Dorsal proximal width of patella $\mathrm{I}=0.5$, tibial index $=12.9$; leg I formula $=3.4$. Leg IV: femur 3.3, patella 1.3, tibia 2.7, metatarsus 2.9, tarsus 2.0. Total $=12.2$. Dorsal proximal width of patella IV $=0.5$, tibial index $=12.6$; leg IV formula $=1.7$.

Pedipalp: length of femur 1.4, patella 0.9, tibia 1.2, tarsus (dorsal) 0.6; embolus basally straight with acute tip (as in paratype, Figures $5 \mathrm{~A}-\mathrm{C}$ ).

Abdomen: length 3.3, width 1.9.

Variation: total length 6.1-7.5, carapace length 2.4-3.1, carapace width 2.3-3.0 $(n=10)$. Maxillary cuspules absent in some specimens.
Variation: The two paratype males are of similar size as the holotype (WAM T97348: total length 8.5, carapace length 3.0, carapace width 2.6; WAM T97349: total length 7.2, carapace length 2.7, carapace width 2.6).

Female

Currently unknown.

\section{Etymology}

The specific name refers to the type locality, the Morgan Ranges in eastern Western Australia.

\section{Distribution}

Swolnpes morganensis is currently only known from the type locality, the Morgan Ranges in eastern Western Australia (Figure 6). The species must currently be considered a short-range endemic after Harvey (2002).

\section{ACKNOWLEDGMENTS}

We are indebted to Ecologia Environment, Perth, in particular Magdalena Davis, for making the S. darwini specimens available for study. VWF was funded by Rio Tinto and Aquila Resources when this study was compiled. We thank Alicia Sutton and Wally Gibb, School of Animal Biology, University of Western Australia, for technical support. 




Figure 6 Distribution records of Swolnpes gen. nov.: Swolnpes darwini (open circles), S. morganensis (full circle).

\section{REFERENCES}

Environmental Protection Authority (2009). Guidance for the Assessment of Environmental Factors (in accordance with the Environmental Protection Act 1986). Sampling of Short Range Invertebrate Fauna for Environmental Impact Assessment in Western Australia. No. 20, Perth.

Darwin, C. (1859). The Origin of Species by Means of Natural Selection. Murray : London.

Goloboff, P.A. (1995). A revision of the South American spiders of the family Nemesiidae (Araneae, Mygalomorphae). Part I: species from Peru, Chile, Argentina, and Uruguay. Bulletin of the American Museum of Natural History 224: 1-189.

Harvey, M.S. (2002). Short-range endemism among the Australian fauna: some examples from non-marine environments. Invertebrate Systematics 16: 555-570.

Hedin, M. and Bond, J.E. (2006). Molecular phylogenetics of the spider infraorder Mygalomorphae using nuclear rRNA genes (18S and 28S): conflict and agreement with current systems of classification. Molecular Phylogenetics and Evolution 41: 454-471.

Main, B.Y. (1985). Further studies on Australian Diplurinae: a review of the genera of the Teylini (Araneae: Mygalomorphae: Dipluridae). Australian Journal of Zoology 33: 743-759.
Main, B.Y. (1986). Further studies on the systematics of Australian Diplurinae (Araneae: Mygalomorphae: Dipluridae): A new genus from south-western Australia. Records of the Western Australian Museum 12: 395-402.

Main, B.Y., Sampey, A. and West, P.L.J. (2000). Mygalomorph spiders of the southern Carnarvon Basin, Western Australia. Records of the Western Australian Museum Supplement 61: 281-293.

Petrunkevitch, A. (1942). A study of amber spiders. Transactions of the Academy of Arts and Sciences 34: 119-464.

Raven, R.J. (1981). A review of the Australian genera of the mygalomorph spider subfamily Diplurinae (Dipluridae: Chelicerata). Australian Journal of Zoology 29: 321-363.

Raven, R.J. (1985). The spider infraorder Mygalomorphae (Araneae): cladistics and systematics. Bulletin of the American Museum of Natural History 182: 1-180.

Raven, R.J. (2000). Taxonomica Araneae I: Barychelidae, Theraphosidae, Nemesiidae and Dipluridae (Araneae). Memoirs of the Queensland Museum 45: 569-575.

Manuscript received 18 June 2009; accepted 2 September 2009. 